\title{
A new sawshark, Pristiophorus laevis, from the Eocene of Antarctica with comments on Pristiophorus lanceolatus
}

\author{
Andrea Engelbrecht ${ }^{\mathrm{a}}$, Thomas Mörs ${ }^{\mathrm{b}}$, Marcelo A. Reguero ${ }^{c}$ and Jürgen Kriwet $^{\mathrm{a}}$ \\ aFaculty of Earth Sciences, Geography and Astronomy, Department of Palaeontology, University of Vienna, Wien, Austria; ${ }^{\mathrm{b}}$ Department of Palaeobiology, \\ Swedish Museum of Natural History, Stockholm, Sweden; 'División Paleontologìa de Vertebrados, Museo de La Plata, CONICET, La Plata, Argentina
}

\begin{abstract}
The highly fossiliferous Eocene deposits of the Antarctic Peninsula are among the most productive sites for fossil remains in the Southern Hemisphere and offer rare insights into high-latitude faunas during the Palaeogene. Chondrichthyans, which are represented by abundant isolated remains, seemingly dominate the marine assemblages. Eocene Antarctic sawsharks have only been known from few isolated rostral spines up to now, that were assigned to Pristiophorus lanceolatus. Here, we present the first oral teeth of a sawshark from the Eocene of Seymour Island and a re-evaluation of previously described Pristiophorus remains from Gondwana consisting exclusively of rostral spines. The holotype of Pristiophorus lanceolatus represents a single, abraded and insufficiently illustrated spine from the Oligocene of New Zealand. All other Cenozoic rostral spines assigned to this species are morphologically very indistinct and closely resemble those of living taxa. Consequently, we regard this species as dubious and introduce a new species, Pristiophorus laevis, based on oral teeth. The combination of dental characteristics of the new species makes it unique compared to all other described species based on oral teeth. Rostral spines from the Eocene of Seymour Island are assigned to this new species whereas those from other Cenozoic Gondwana localities remain ambiguous.
\end{abstract}

LSID urn:Isid:zoobank.org:pub:7177A373-527B-4315-85F6-25180DB5E087

\section{ARTICLE HISTORY}

Received 31 August 2016

Accepted 21 October 2016

\section{KEYWORDS}

Seymour Island; Palaeogene; Southern Ocean;

Pristiophoridae; new taxon

\section{Introduction}

The family Pristiophoridae Bleeker, 1859 (Pristiophoriformes Berg, 1958) is an ancient group of squalomorph elasmobranchs with a fossil record extending back into the Early Cretaceous, some 110 Myr ago (Keyes 1982; Kemp 1991). They are characterized by a dorso-ventrally flattened body and hypertrophied rostrum lined laterally by saw-teeth, which evolved convergently to the elongated and toothed rostrum in sawfishes of the family Pristidae Bonaparte, 1838 (Pristiformes Compagno, 1973) that belongs to batomorphs. The saw-teeth of sawsharks and sawfishes are, however, not homologous to oral teeth and are better named rostral spines (Smith et al. 2015). Major differences between sawsharks and sawfishes include non-growing and unequally large rostral spines that are usually arranged in an alternating pattern and only weakly anchored in the tissue rather than being set in sockets of the rostral cartilage, small additional rostral spines on the ventral side of the rostrum, and a pair of long ventral barbels anterior to the nostrils. The rostrum in saw-bearing elasmobranchs both are used to detect electric fields of possible prey and capture prey by stunning or disabling the prey with strikes of the rostral saw (Frazzetta 1994; Wueringer et al. 2012).

Living sawsharks comprise eight valid marine species representing two different genera, Pliotrema (Regan 1906) with a single species and Pristiophorus (Müller \& Henle 1837) with seven species, respectively. While pristiophorids were distributed globally in the past, their modern-day occurrences are seemingly more restricted. They are confined to the western North Atlantic, the south-eastern Atlantic, the western Indian Ocean, the Arabian Sea, and the western Pacific inhabiting continental and insular shelves, and upper slopes in temperate regions and deeper waters in the tropics (Compagno et al. 2005). According to Musick et al. (2004) modern sawsharks have highest diversities in waters around Australia, relict areas in the Atlantic Ocean, but are extinct in the eastern Pacific. No species occurs in polar seas today (Ebert \& Winton 2010).

Fossil pristiophorids are mainly known from isolated rostral spines that were used in the past to define species (e.g. Davies 1888; Applegate \& Uyeno 1968), whereas oral teeth are very rare as fossils. The only known skeletal remains come from the upper Santonian of Lebanon (Cappetta 1980). A third, extinct pristiophorid genus, Ikamauius (Keyes 1979), was erected for isolated rostral spines from the Cenozoic of New Zealand (Keyes 1979). The rostral spines resemble those of the extant Pliotrema to some extent. Rostral spines of Pliotrema, however, can be easily identified by having strongly notched anterior and posterior cutting edges. Fossil remains of Pliotrema also are very rare and only a few records from the Palaeocene of North America and Miocene of South Africa are known (Case 1973; 


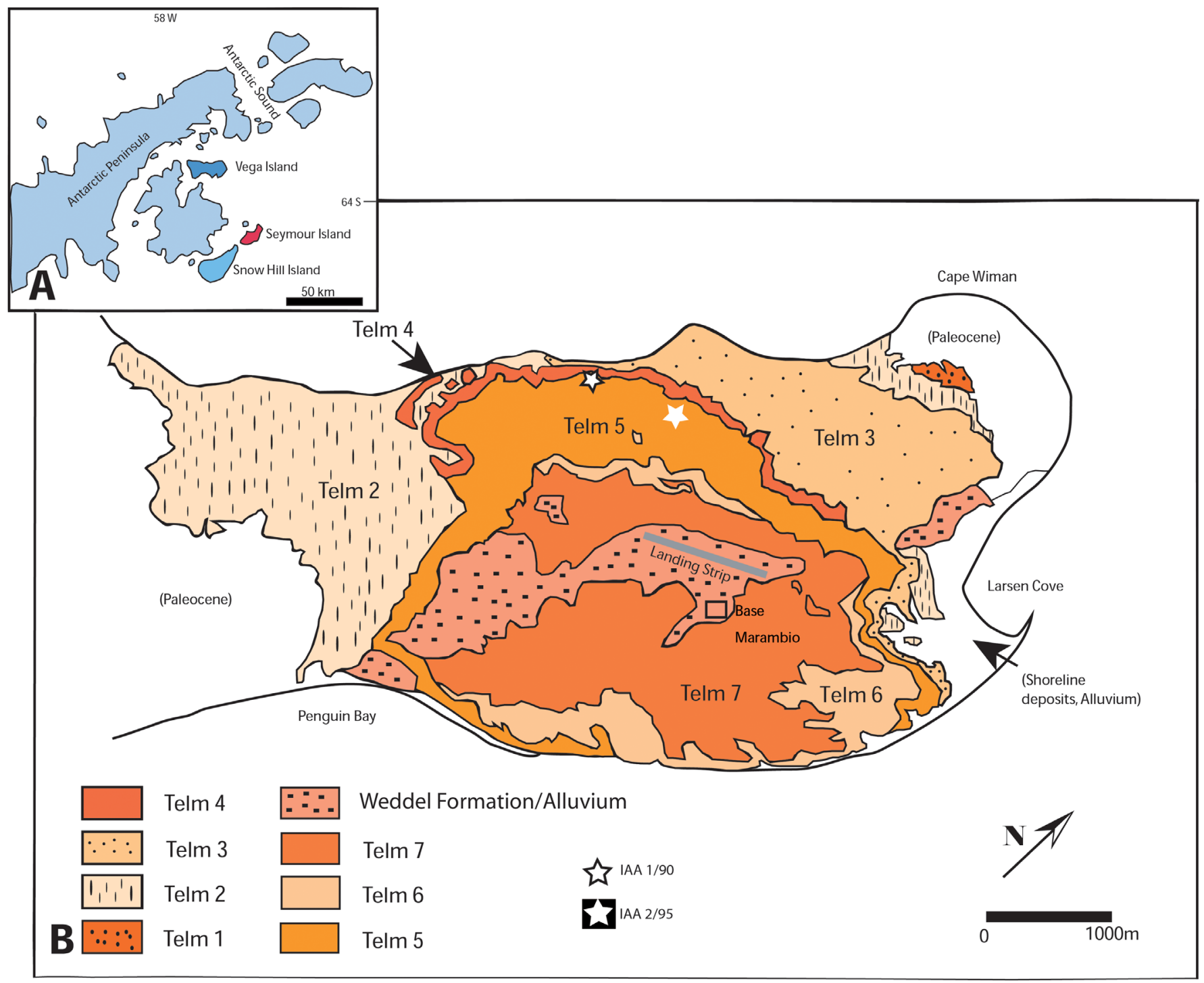

Figure 1. Geological maps of Seymour Island, Antarctic Peninsula. (A) Index map of Seymour Island. (B) Geological map of Seymour Island, showing the outcrop of TELM 5 and localities IAA 1/90 and IAA 2/95 of the Eocene La Meseta Formation.

Welton 1974; Keyes 1982). Fossil remains, especially isolated rostral spines of Pristiophorus, conversely, are quite abundant and occur in many Late Cretaceous and Cenozoic marine localities. Rostral spines in extant species provide only few morphological traits and additionally display high degrees of intra-specific and ontogenetic variations rendering any species assignment of fossil taxa based on isolated rostral spines almost impossible. Thus, any species based strictly on these remains should be considered dubious (Underwood \& Schlögl 2013; this study). Only five extinct species, Pristiophorus tumidens (Woodward 1932) from the Santonian, P. lacipidinensis Adnet 2006 from the Eocene, $P$. rupeliensis Steurbaut and Herman 1978 from the Oligocene, and P. striatus Underwood and Schlögl 2013 from the Miocene, were erected for teeth and can be considered valid. Records of these five species only are known from the Northern Hemisphere.

The purpose of this paper is to present the first unambiguous record of an extinct sawfish from the Southern Hemisphere, which is represented by isolated oral teeth and rostral spines from the Eocene of Antarctica. So far, pristiophorid remains from the Eocene of Antarctica only included isolated rostral spines that were assigned to Pristiophorus lanceolatus (e.g. Grande \& Eastman 1986; Long 1992a, 1992b; Tambussi et al. 2006; Reguero et al. 2012; Kriwet et al. 2016), a species originally based on a very abraded rostral spine from the Oligocene of New Zealand by Davies (1888). The dental material presented here allows a re-evaluation and revision of these previous Antarctic finds. Additionally, the palaeogeographic distribution of Pristiophorus spp. is reviewed.

\section{Locality and stratigraphical setting}

Argentinian-Swedish field parties, as a joint project of the Instituto Antártico Argentino (DNA-IAA) and the Swedish Polar Research Secretary (SPFS), collected the material described herein during three Antarctic summer campaigns in 2011, 2012 and 2013 on Seymour Island off the Antarctic Peninsula in the Weddell Sea. 
Highly fossiliferous sediments of the La Meseta and Submeseta formations are exposed in the northernmost part of West Antarctica, which is comprised of several tectonic blocks (Vaughan \& Pankhurst 2008; Michaux 2009). These deposits provide a unique opportunity to study taxonomic compositions and the faunal turnover in Eocene ecosystems. Isolated shark teeth are the most abundant fossils on Seymour Island, but also remains of teleosts, whales, terrestrial mammals, penguins and flying birds as well as invertebrate and plant remains have been recovered (e.g. Marenssi et al. 1994; Doktor et al. 1996; Kriwet 2003; Schweitzer et al. 2005; Jadwiszczak \& Mörs 2011, 2016; Reguero et al. 2012; Bomfleur et al. 2015; Gelfo et al. 2015; Buono et al. 2016; McLoughlin et al. 2016; Schwarzhans et al. 2016).

Fossiliferous sediments on Seymour Island belong to two groups, the lower Marambio Group (Lopez de Bertodano and Sobral formations) spanning from the Late Cretaceous to the Paleocene and the overlying Seymour Island Group (Cross Valley and La Meseta formations), which ranges from the Paleocene to the Late Eocene/?earliest Oligocene (e.g. Zinsmeister 1982; Grande \& Chatterjee 1987). Montes et al. (2013) recently published a geological map of Seymour Island with improved age information for the Eocene marine horizons and stratigraphic sequences. The sedimentary Palaeogene sequence on Seymour Island is now divided into two geological units, the La Meseta and Submeseta formations. These formations are separated and bounded by a prominent erosional surface (Marenssi 2006). The La Meseta Fm. is an unconformity-bounded unit (Elliot \& Trautman 1982; Ivany et al. 2008) and is organized into five erosionally based allomembers named Valle de Las Focas (TELM 1), Acantilado (TELMs 2/3), Campamento (TELM 3), Cucullaea I (TELMs 4/5) and Cucullaea II (TELM 5) (Marenssi et al. 1998b; Montes et al. 2013). The recently defined Submeseta Fm. (Montes et al. 2013) corresponds to the uppermost part of the sedimentary sequence and is organized into three allomembers named Submeseta I (TELM 6), Submeseta II (TELM 7) and Submeseta III (TELM 7). The base of the unit is placed at 43.4 Ma (upper Lutetian) and the top at 33.9 Ma (Priabonian/Rupelian) according to Montes et al. (2013).

The depositional environment of the La Meseta and Submeseta formations is interpreted as having accumulated in estuarine, deltaic, or shallow marine settings (Marenssi et al. 1998a, 1998b). Geochemical evidence derived from fossil shell material suggests a considerable cooling event (Gazdzicki et al. 1992) during the deposition of the Submeseta Fm. (TELMs 6 and 7). The material that forms the focus of this study was recovered from the Cucullaea I Allomember of TELM 5 (late Ypresian), which occurs in the middle part of the La Meseta Fm. at two fossil sites, IAA 1/90 (GPS data: 64²14'04.67"S; $56^{\circ} 39^{\prime} 56.38^{\prime \prime} \mathrm{W}$, Figure 1), which is also named 'Ungulate Site' (e.g. Bond et al. 1990; Reguero et al. 2013) and IAA 2/95 (GPS data: $64^{\circ} 13^{\prime} 58^{\prime \prime}$; $56^{\circ} 39^{\prime} 06^{\prime \prime} \mathrm{W}$, Figure 1), informally known as the 'Marsupial site'. The late Ypresian TELM 5 comprises well-laminated sediments and consists mostly of fine-grained sandstones and silty clays, with interbedded conglomeratic sandstones (Sadler 1988). Stilwell and Zinsmeister (1992) consider the depositional setting of Cucullaea I Allomember to represent a nearshore, ebb-tidal delta-barrier island complex, which was strongly influenced by waves and tidal currents.

\section{Material and methods}

Bulk samples were collected from both sites, IAA 1/90 and IAA $2 / 95$, to obtain also teeth of small-sized vertebrates. All bulk samples were dry-sieved in the field, separated into different size fractions $(2,0.5,0.2 \mathrm{~mm})$ and subsequently sorted under a stereomicroscope for invertebrate and vertebrate remains. The vertebrate material contains predominantly isolated elasmobranch teeth and placoid scales including the oral and rostral spines of the sawshark described here. Additionally, larger rostral teeth were obtained through surface collecting.

The oral teeth were studied with the help of a JEOL- 6400 scanning electron microscope (SEM) at the Department of Palaeontology, University of Vienna. Before sputter coating (Sputter Coater SC 500), the teeth were cleaned with Rewoquat ${ }^{\oplus}$ and mounted on stubs. Rostral teeth were photographed with a reflex camera and/or a 3D digital microscope (Keyence VHX$1000 \mathrm{D} 3 \mathrm{D})$. The morphological terminologies and systematic framework used here follows those of Cappetta (2012).

\section{Systematic palaeontology}

Supraclass Chondrichthyes Huxley 1880

Class Elasmobranchii Bonaparte 1838

Cohort Euselachii Hay 1902

Subcohort Neoselachii Compagno 1977

Superorder Squalimorphii Compagno 1973

Order Pristiophoriformes Berg 1958

Family Pristiophoridae Bleeker 1859

Genus Pristiophorus Müller and Henle 1837

Type species: Pristis cirratus Latham 1794; extant

Pristiophorus laevis sp. nov.

Figure 2(A1-D4)

1986 Pristiphorus lanceolatus Davies; Grande and Eastman, pp. 123, text-fig. 3.

1992a Pristiophorus lanceolatus Davies; Long, pp. 20, fig. 3.

1998 Pristiophorus lanceolatus Davies; Cione and Reguero, pp. 84, Tab. 1.

2005 Pristiophorus lanceolatus Davies; Kriwet, pp. 7, Tab. 1.

2006 Pristiophorus lanceolatus Davies; Tambussi et al., pp. 159, Tab. 4.

2012 Pristiophorus lanceolatus Davies; Reguero et al., pp. 278, Tab. 1.

2016 Pristiophorus lanceolatus Davies; Kriwet et al., pp. e1160911-6 - e1160911-8, fig. 5.

\section{Etymology}

The species name is derived from the Latin adjective 'laevis' meaning 'smooth', 'not rough' referring to the smooth cusp of the oral teeth and the rostral spines.

Holotype. A single oral tooth, NRM-PZ P. 16055 (Figure 2(A1-A4)). 


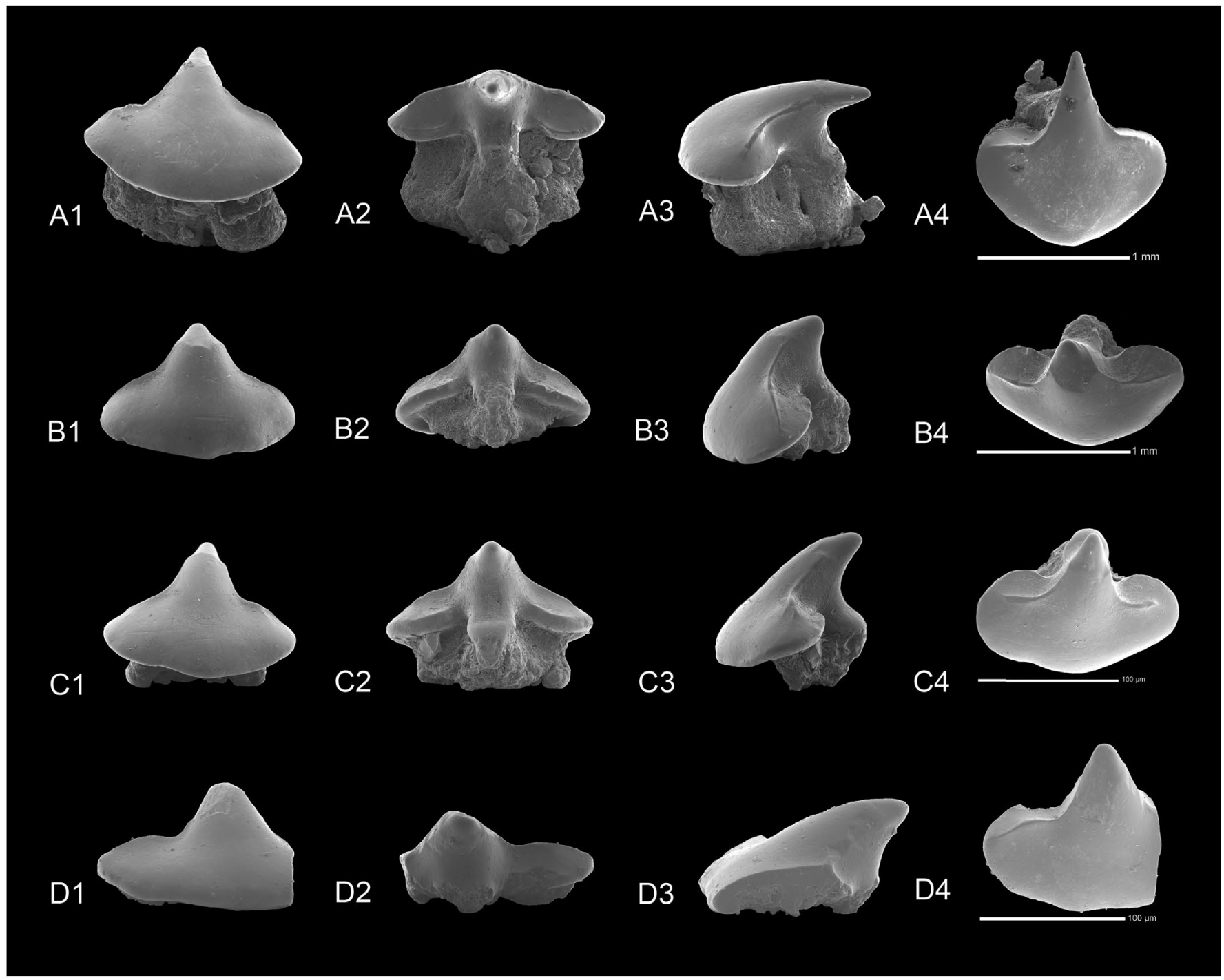

Figure 2. SEM photographs of oral teeth of Pristiophorus laevis sp. nov. NRM-PZ P. 16055 A1: labial, A2: lingual, A3: profile, A4: occlusal views. NRM-PZ P. 16056 B1: labial, B2: lingual, B3: profile, B4: occlusal views. NRM-PZ P. 15914: C1: labial, C2: lingual, C3: profile, C4: occlusal views. NRM-PZ P. 16057: D1: labial, D2: lingual, D3: profile, D4: occlusal views. Scale bar equals $1 \mathrm{~mm}$.

\section{Type locality}

Site IAA 2/95 (GPS data: 64¹3'58”S; 56³9’06”W), Cucullaea I Allomember, TELM 5, La Meseta Formation, Seymour Island, Antarctica, Ypresian, Early Eocene.

\section{Paratypes}

Oral teeth from site IAA 1/90: NRM-PZ P. 16056 to NRM-PZ P.16057 and NRM-PZ P. 15914. Rostral spines from site IAA 2/95: NRM-PZ P. 15934, NRM-PZ P. 16058 to NRM-PZ P.16061 and NRM-PZ P. 16064. Rostral spines from site IAA 1/90 NRM-PZ P. 16062 and NRM-PZ P. 16063 (seven specimens) Figure 3(A1-C4) (depicted). Cucullaea I Allomember, TELM 5, La Meseta Formation, Seymour Island, Antarctica, Ypresian, Early Eocene.

\section{Additional material}

All additional material consist exclusively of rostral spines:
TELM 3 (Ypresian, Early Eocene): RV-8436, UCMP 322079, one specimen.

TELM 4 (Ypresian, Early Eocene): DPV 2/84 (Whale Jaw Site), one specimen, NRM-PZ P. 16076; NRM 6, one specimen, NRM-PZ P. 16077; IAA 1/11, NRM-PZ P. 16078; UCMP 322081, UCMP 322081, UCMP 321239, UCMP 322083, UCMP 322196 , MOW 8660, (without collection number: 121 specimens); RV-8424, 14 specimens, UCMP 322080 (without collection number: 13 specimens).

TELM 5 (Ypresian, Early Eocene): IAA 1/90, 347 specimens, NRM-PZ P. 16066; IAA 2/95, 516 specimens, NRM-PZ P. 16067; Natica-Horizon, GPS 31, 45 specimens, NRM-PZ P. 16068; Natica-Horizon, south of IAA 1/90, 1 specimen, NRM-PZ P. 16069; Natica-Horizon, GPS 64, 48 specimens, NRM-PZ P. 16070; NRM 1, two specimens, NRM-PZ P. 16071; Monotreme Site, two specimens, NRM-PZ P. 16072; DPV 6/84 (Rocket Site), one specimen, NRM-PZ P. 16073; Wild North, one specimen, NRM-PZ P.16074; south of Marsupial Site, four specimens, NRM-PZ P. 16075; RV-8200, 131 specimens. 


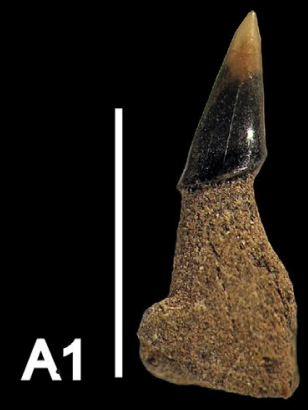

A2
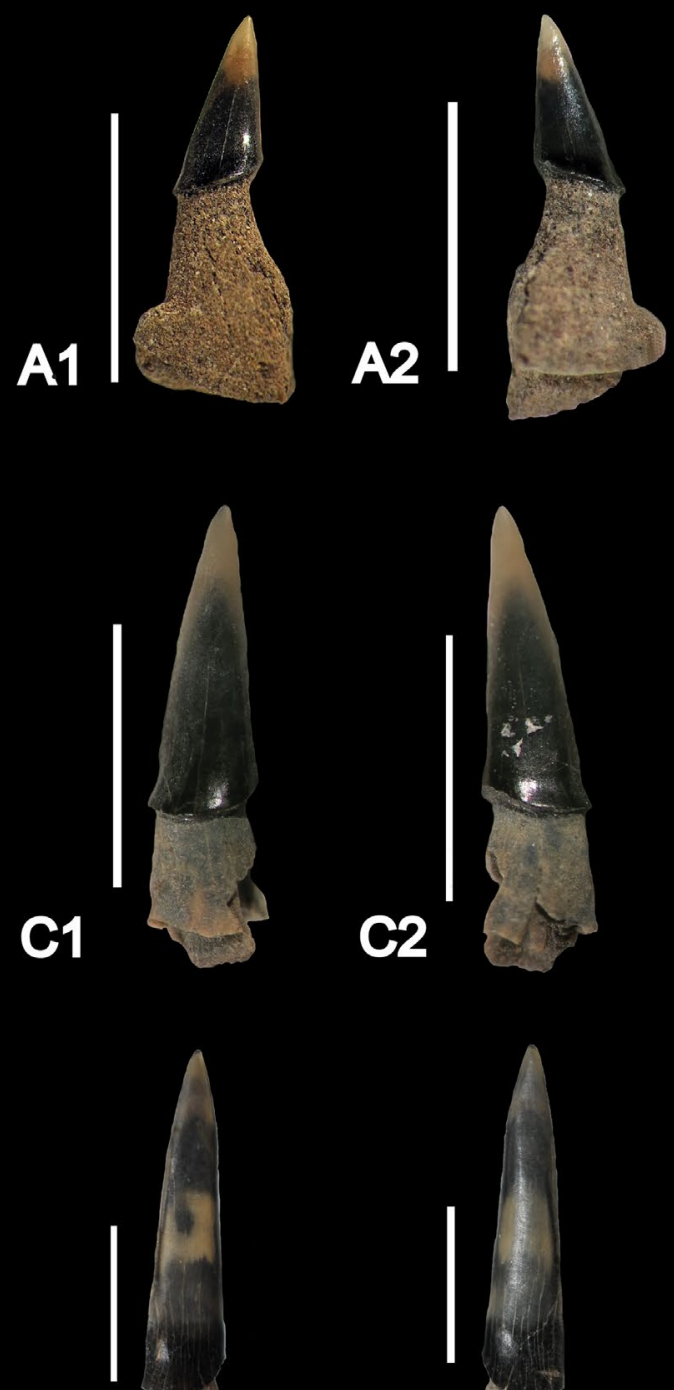

E1
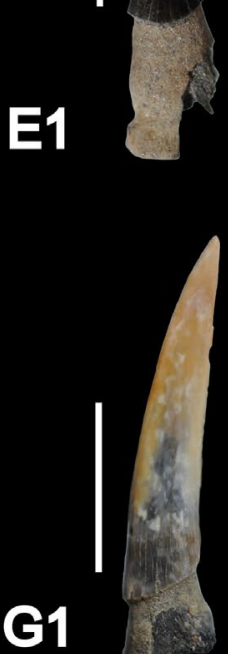
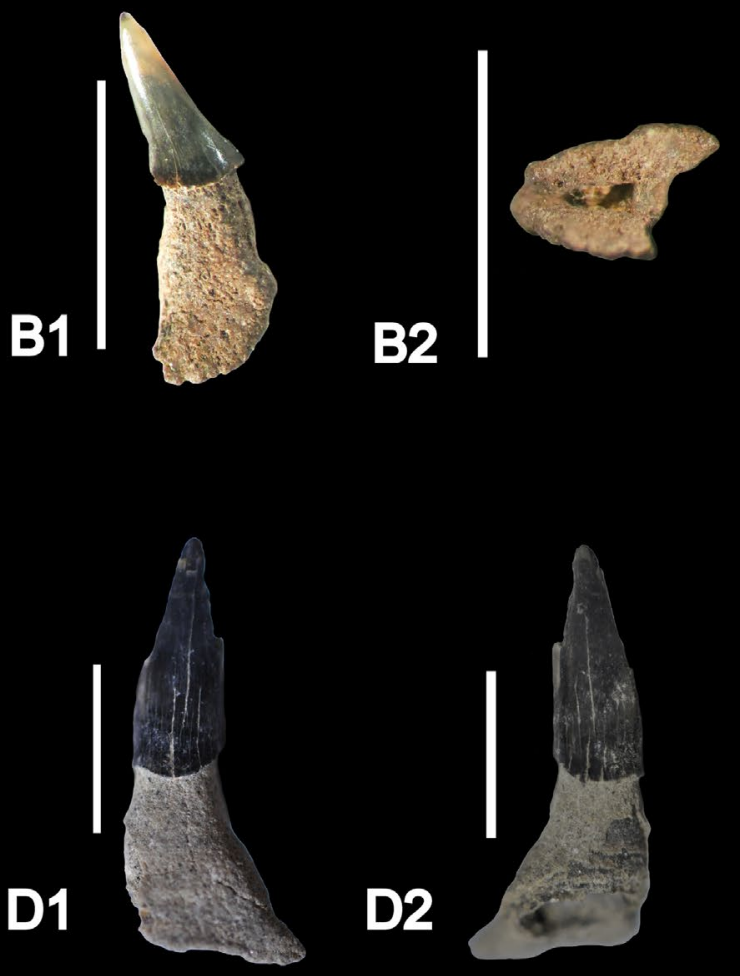

$\mathbf{F 1}$
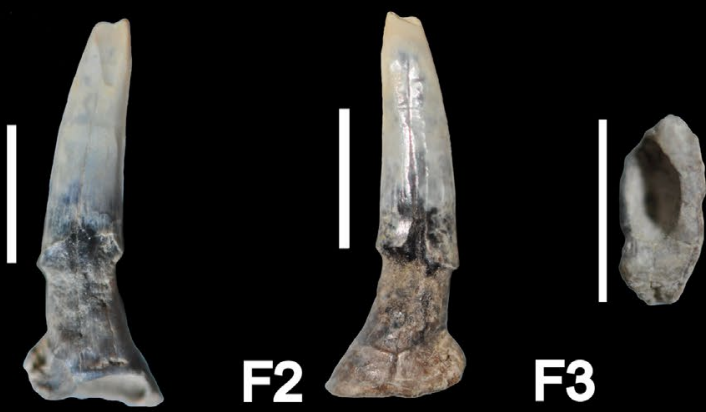

F3

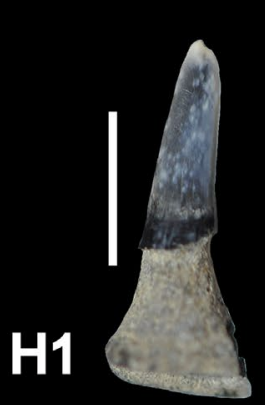

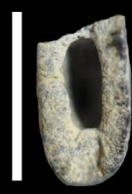

H3

Figure 3. Pictures of rostral spines of Pristiophorus laevis sp. nov., NRM-PZ P. 16058: A1: dorsal view, A2: ventral view. NRM-PZ P. 16059: B1: ventral view, B2: basal view. NRM-PZ P. 16060: C1: dorsal view, C2: ventral view. NRM-PZ P. 16061: D1: dorsal view, D2: ventral view. NRM-PZ P. 16062: E1: dorsal view, E2: ventral view. NRM-PZ P. 16063: F1: dorsal view, F2: ventral view, F3: basal view. NRM-PZ P. 16064: G1: dorsal view, G2: ventral view. NRM-PZ P. 15934: H1: dorsal view, H2: ventral view, H3: basal view. Scale bar equals $5 \mathrm{~mm}$. 
TELM 6 (Lutetian, Middle Eocene): IAA 1/93, 25 specimens; NRM-PZ P. 16065.

TELM 7 (Priabonian, Late Eocene): NRM 2, one specimen, NRM-PZ P. 16006.

\section{Diagnosis}

A new species of Pristiophorus defined by the following combination of dental characters: Teeth with low, broad, and rather pointed principal cusp in labial view. Apex of cusp significantly curved lingually. No lateral cusplets. Labial crown face completely smooth, devoid of any ornamentation such as striae or costules. Broad lobed distal and mesial part of crown with distinct cutting edge; not reaching to the apex of the central cusp. Apron broad with semicircular labial edge, not well separated and overhanging root labially and laterally forming a distinct rim. Horizontal or slightly oblique ridges present lingually below crown (depending on jaw position) shoulders and on uvula. Uvula is prominent and rather broad. Tooth root high with few foramina on the lingual side.

\section{Differential diagnosis}

The character combination of the low and strongly lingually inclined principal cusp with completely smooth labial crown face, lingual horizontal ridges on lower portion of crown shoulders and on uvula, a rather broad and completely unornamented enameloid spanning from both sides of the lingual uvula, and a high root with few foramina readily distinguish Pristiophorus leavis sp. nov. from extant and extinct taxa. The Late Cretaceous Pristiophorus tumidens Woodward, 1932 is characterized by an erect principal cusp, with a tumid base bearing delicate vertical striae. The Oligocene species, Pristiophours rupeliensis (Steurbaut \& Herman, 1978); has a smooth labial and lingual crown face, but possesses on both sides of the apron small irregularly shaped costules and the uvula is strongly protuberant on the lingual face. The labial crown face of the Eocene species Pristiophorus lacipidinensis Adnet, 2006 and the Miocene species Pristiophorus striatus Underwood and Schlögl, 2013 bears irregular striations unlike to the new species described here. Teeth of Pristiophorus striatus are also far wider than high and have a weakly rhombic and short labial crown face and a very low principal cusp. Teeth of the extant Pliotrema warreni Regan, 1906 are characterized by an irregularly shaped apron, which is well detached and separated from the labial crown face and the mesial and distal crown base parts curve strongly towards the apex of the crown forming a sharp notch with the uvula.

\section{Description}

A total of four oral teeth and numerous rostral spines are assigned to the new pristiophorid species described here. All teeth display a low and basally rather broad principal cusp. The labial crown face lacks any ornamentation. Laterally, the crown shoulder is sub-rhombic in labial view with tapering lateral edges. The labial apron is not demarcated from the labial face but broad and convex to almost straight in labial view. It overhangs the root laterally and labially with a rather broad rim that has an almost horizontal lower surface. The cutting edges are prominent and continuous between cusp and crown shoulder but do not reach the apex in any of the four preserved specimens. Lingually, a more or less developed salient bulge is present at the lower portion of the tooth and on the uvula. The upper part of the crown shoulders are concave and tapering upwards. Vertical striae or costules are absent. The mesial and distal portions of the lingual crown shoulders are slightly curved towards the apex forming a rather blunt notch with the uvula. The root is high and possesses only a few foramina on the lingual side of the root.

The holotype, NRM-PZ P. 16055, is as high as wide. The crown shoulder makes up half of the total height of the crown. The crown overhangs the root on three sides (labial, mesial, distal). The principal cusp is low and triangular in labial view with straight lateral edges (Figure 2(A1)). The apex is very acute and extremely inclined lingually in lateral view giving the crown a hook-shaped appearance. The labial face is more or less horizontal in profile view (Figure 2(A3)). It is completely devoid of any ornamentation such as striae or costules. Some faint scratches due to abrasion are present on the middle portion of the crown. The labial face is only very slightly convex in profile view. Compared to the other described teeth, the apron is not that prominent and protruding. It is convex in profile view (Figure 2(A3)), rounded in labial view (Figure 2(A1)) and slightly overhangs the crown-root junction, but is not individualized from the labial crown face.

In occlusal view the crown shoulder appears heart-shaped, the cusp is very slender and pointed. The mesial and distal portions of the crown shoulder are tapering upwards. The cutting edges of the tooth start in the middle of the principal cusp and close to the edges of the broadened lateral crown shoulder portions (Figure 2(A3)). In occlusal view the cutting edge at the transition from principal cusp to the lateral parts of the crown is rather straight and acute compared to the other oral teeth of this species. Lateral cusplets are absent.

The lingual face of the crown shoulder is almost flat but slightly convex from side to side at the level of the cusp, which is expanded basally to form a short and narrow, slightly tapering uvula (Figure 2(A3)). Lingually, a faint horizontal ridge is present on the lower portions of the lateral crown shoulders and on the uvula close to the basal edge (Figure 2(A2)). The lingual crown face is smooth without any ornamentation. When observed in lingual view the main cusp appears heavily worn (Figure 2(A2)).

The root is high with a hemiaulacorhize vascularisation pattern, but partly damaged. It is less wide than the crown. The basal face is flat. The lateral lobes are not well separated with a laterally displaced and narrow grove separating the root lobes anteriorly. The root lobes are slightly flared laterally in labial view. In profile view, two pairs of drop-shaped margino-lingual foramina are present, of which the anterior one is smaller than the posterior one. The lingual foramen is small and basally placed on the lingual face of the root. The basal face of the root is eroded, only the sub rectangular cavity is clearly present.

NRM-PZ P. 16056 is very damaged missing most of the root. The crown is wider than high, with a low and broad, triangular shaped principal cusp. In labial view the apex of the principal cusp shows some indications of abrasion (Figure 2(B2)). No lateral cusplets are present. In profile view (Figure 2(B3)) the labial crown face is slightly concave in the middle of the crown, but very convex where the apron begins to protrude. The cusp is less 
curved lingually in comparison to the holotype. The apex is bent and in labial view it seems that the crown is more or less horizontal. The lingual crown face is slightly concave in profile view.

The labial crown face is devoid of any ornamentation, only one shallow scratch is present in the middle of the apron. The cutting edge continuously runs across the mesial and distal lateral parts of the crown but does not reach the apex of the principal cusp and the lateral edges of the crown shoulder (Figure 2(B3)). In occlusal view the cutting edge is convex at the transition from principal cusp to the lateral parts of the crown. The lateral parts of the crown shoulder are wide and broadly lobed with rounded lateral edges in labial view (Figures 2(B1) and (B3)). The apron is short and broadly united to the labial crown face, semi-circular and not well individualized. It overhangs the root labially (Figure 2(B3)). The lingual crown face is concave with a slightly inclined apex. In lingual view, a well-developed straight and slightly obliquely arranged bulge at the lower parts of the crown shoulders is present, as well as on the base of the uvula (Figure 2(B2)). The lingual crown face is completely smooth, almost flat at the level of the crown shoulder and more convex at the level of the cusp. Basally, the cusp extends into a short and slightly tapering uvula.

NRM-PZ P. 15914 is wider than high, with an almost rhombic crown shoulder in labial view. The lateral edges of the crown shoulders are tapering slightly and have rounded distal and mesial edges. The cusp is broad at its base and triangular shaped and low principal cusp. It is inclined lingually, but to a lesser degree than the holotype. The apex is additionally bent lingually (Figure 2(C3)). It shows some signs of abrasion on the upper part in labial view (Figure 2(A3)). The lower part of the crown makes up half of the total crown height. The labial crown face is unornamented. It forms a broad, semi-circular and protruding apron, which overhangs the root lingually and is not separated from the principal cusp (Figure 2(C1) and (C3)). The cutting edges are prominent but do not reach the apex of the principal cusp or the lateral edges of the crown shoulder. In occlusal view, the cutting edge is convex at the transition from the principal cusp to the lateral parts of the crown. No lateral cusplets are present (Figure 2(C1)). The lingual crown face is devoid of any ornamentation and is strongly concave in profile view. The cusp is lingually inclined. The additional ridge close to the basal edge of the lingual face on the crown shoulders is very prominent almost forming a terrace-like structure in occlusal view. The mesial additional ridge is straight whereas the distal one is slightly concave. An additional short but also distinct ridge is present on the uvula (Figure 2(C2)). The median lingual uvula is prominent, not that long and covered with enameloid at the upper part and devoid of enameloid at the lower region. The root is heavily damaged and does not provide any additional or detailed information regarding the nutritive foramina.

NRM-PZ P. 16057 is heavily damaged lacking the root completely and one lateral crown shoulder (Figure 2(D1)). The crown is distinctly mesio-distally elongated indicating that the crown was wider than high. There is a low, triangular principal cusp, with a rounded but abraded apex. The labial crown face is devoid of any ornamentation. In profile view the labial face of the crown is only slightly convex whereas the lingual crown face is concave. The cusp is rather broad in profile view and curved lingually. Additionally, the cusp is asymmetric in labial view and therefore, slightly inclined distally. The basal rim of the labial face is almost straight without any individualized apron (Figure 2(D1)). Lateral cusplets are absent. The preserved lateral crown shoulder is very low compared to the cusp with a tapering lateral edge. The cutting edges are short and hardly visible, compared to the other specimens (Figure 2(D3)). In occlusal view the cutting edge makes a slightly concave curve at the junction of the principal cusp to the lateral parts of the crown.

Rostral spines are more abundant in fossil sites and present throughout the La Meseta and Submeseta formations. Smooth enameloid caps (or cusps) and basal peduncles (or roots) characterize the rostral spines of this species. The enameloid cap is laterally elongated, slender and markedly dorso-ventrally compressed (Figure 3). The cap is horizontal to slightly bend ventrally, depending on the position of the rostral spine on the rostrum. The anterior and posterior edges of the cap are slightly tapering laterally and the apex is very pointed (Figure $3(\mathrm{C})$ and $(\mathrm{G})$ ). The dorsal and ventral surfaces of the cap are completely smooth and devoid of any ornamentation. The anterior and posterior cutting edges are dull and without serrations or crenulations. The anterior and posterior margins of the cap are very thin at the apex but becoming thicker towards the base of the cap. The cap is wider than the peduncle and overhangs the latter on all sides. Where the cap and the peduncle meet, the basal edges of the cap are semi-circular and bulging outwards. The anterior part of the cap is longer than the posterior part.

The peduncle is cylindrical in its upper portion but become antero-posteriorly elongated in its basal region. It is rather high and prominent in most specimens. The basal face of the peduncle is flat and characterized by an elliptically and deeply set elongated foramen. The size of the rostral spines varies (minimum size of about $3 \mathrm{~mm}$ and a maximum size of about $18 \mathrm{~mm}$ in height) according to the position on the rostrum or ontogenetic stage (Figure 3(F3) and (H3)).

\section{Remarks}

Sawshark remains assigned to Pristiophorus were frequently recorded from Seymour Island in the past (e.g. Grande \& Eastman 1986; Long 1992a; Otero et al. 2014; Kriwet et al. 2016). However, these records have been based exclusively on rostral teeth up to now. The oral teeth of the new described species, Pristiophorus laevis sp. nov. display all characteristic traits of teeth of Pristiophorus but differ from all known species based on teeth in a suite of characters outlined. Teeth of Pristiophorus can easily be distinguish from teeth of the extant Pliotrema warreni (Regan 1906) by the lack of a distinctive apron, which is clearly separated from the labial crown face by a very deep notch. Also the outline of the basal edge of the crown differs from Pristiophorus in not being furrowed. Furthermore, the cutting edges are less marked. The mesial and distal crown shoulder portions are curved strongly towards the apex of the crown to form a sharp notch with the uvula in Pliotrema. Teeth of Pristiophorus laevis sp. nov. slightly differ from teeth of the extant Pristiophorus cirratus (Latham 1794) in having a shorter central cusp and a very short if not absent apron, which is not individualized from the labial crown face. The new species differs from the extant Pristiophorus schroederi (Springer \& Bullis 1960) in lacking a vertical enameloid fold in the middle of the labial face of the 
principal cusp and the lack of short costules at the base of the labial crown face. It also differs from the extant Pristiophorus sp. (Pollerspöck \& Straube 2016) in having a regular and convex outline of the apron, a shorter main cusp and a smooth enameloid surface. Teeth of Pristiophorus rupeliensis (Steurbaut \& Herman 1978) also are characterized by a smooth crown face but costules can appear on both labial and lingual crown face bases and the apron is at least slightly individualized from the labial crown face.

Rostral sawshark spines are very abundant throughout the Eocene La Meseta and Submeseta formations of Antarctica (see below) and almost all specimens have been assigned to Pristiophorus lanceolatus Davies 1888;. This species was originally erected for several rostral spines from different localities in the Oamaru Formation, was assigned to Lamna by Davies (1888, p. 20). The single specimen depicted on his plate 3 in figure 12 clearly is a rostral spine. Keyes (1982) described additional rostral spines of Pristiophorus from the Cenozoic of New Zealand that he identified as P. lanceolatus. However, the figure and the description of Davies (1888) do not provide any detailed morphological information to support any species identification. Moreover, most if not all fossil rostral spines assigned to Pristiophorus are indistinguishable from those of extant species. Therefore, we agree with Underwood and Schlögl (2013) and consider all fossil Pristiophorus spp. based on rostral spines alone as nomina dubia until autapomorphic characters can be established. Consequently, the New Zealand material described by Keyes (1982) should be considered as Pristiophorus sp. We consider the rostral sawshark spines from TELM 5 (Ypresian) of the La Meseta Fm. that co-occur with the oral teeth described herein belongs to Pristiophorus laevis sp. nov. Rostral spines from other TELMs within the La Meseta and Submeseta formations are tentatively allocated to the new species.

The La Meseta rostral sawshark spines share all the same general morphology despite different sizes. This morphology, although very generalized, can nevertheless be used to some extent for taxonomic purposes. All La Meseta rostral sawshark spines are devoid of serrated cutting edges, which are present in rostral spines of extant Pliotrema and extinct Ikamauius spp., and clearly attributes the Antarctic specimens to Pristiophorus. Rostral spines of the Santonian Pristiophorus tumidens (Woodward 1932) and of the Miocene Pristiophorus suevicus (Jaekel 1890) differ in having ornamented crown surfaces unlike to the completely smooth and unornamented crown surfaces of the new species described here. The Oligocene species Pristiophorus lineatus (Applegate \& Uyeno 1968), differs in having rostral spines with parallel arranged cutting edges and a blunt apex in comparison to the rostral spines assigned here to the newly described species. Compared to the extant species $P$. cirratus, the rostral spines differ slightly in the shape of the enameloid cusp, in being straighter and in that the junction between peduncle and crown is blurred in the extant species. The rostral spines of the extant Pristiophorus schoederi are, conversely, curved more posteriorly, appear more delicate and possess some enameloid folds on the crown surface. The peduncle of extant pristiophorid sharks is comparably shorter in relation to the cusp. This character, however, might be age dependent. The rostral spines of recent Pristiophorus sp. (Pollerspöck \& Straube 2016) differ from the fossil La Meseta specimens in having short enameloid folds, which start at the crown base but are very short.

\section{Discussion}

Sawsharks of the family Pristiophoridae are small and slender sharks, which reach a maximum length of $150 \mathrm{~cm}$. They have a cylindrical body, a flattened head, an elongated flat, saw-like rostrum, with a pair of long ventral barbels in front of the nostrils and saw-teeth. Even though sawsharks share some similarities with sawfishes, but they differ in many important characteristics. Sawfishes grow considerably larger than sawsharks, they don't possess barbles and their gills are located ventrally. Extinct sclerorhynchiform sawfishes, which show a mosaic of characters found in sawsharks (e.g. attachment of rostral spines) and sawfishes (e.g. presence of synarcual) (e.g. Kriwet 2004; Smith et al. 2015) are not considered here for comparison because they went extinct at the K/Pg boundary event (e.g. Kriwet \& Benton 2004).

Members of extant Pristiophorus and Pliotrema occur on continental and insular shelves and upper slopes. Most living sawshark species are restricted to the Indo-West Pacific (Figure 5), with Pristiophorus schroederi (Springer \& Bullis 1960) which inhabits the western North Atlantic Pliotrema warreni (Regan 1906) and Pristiophorus nancyae (Ebert \& Cailliet 2011), which are known from the western Indian Ocean being the exception (Compagno et al. 2005). Extinct sawsharks had much wider distributions in the past. Figures 4 and 5 summarize the fossil distribution of Pristiophorus, which is known from the late Early Cretaceous (Albian) to the Upper Oligocene of Japan (e.g. Nishimoto \& Morozumi 1979; Applegate \& Uyeno 1968).

Rostral spines of extinct sawsharks are known from many places worldwide, e.g., Upper Paleocene of Morocco (Herman 1973; Noubhani \& Cappetta 1997), Upper Eocene of Oregon (Welton 1972) and France (Adnet 2000, 2006), Oligocene of Belgium (Steurbaut \& Herman 1978), Miocene of Southwest Germany (Jaekel 1890) and Pliocene of New Zealand (Chapman 1918). Some unidentified taxa were recovered from the Campanian-Maastrichtian boundary of the Upper Cretaceous of Japan (Nishimoto \& Morozumi 1979), Miocene of South America (Cione \& Expósito 1980; De Muizon \& De Vries 1985; Cione 1988; Arratia \& Cione 1996; Suárez \& Marquardt 2001; Suárez et al. 2006) and the Pliocene of Italy (Lawley 1876).

Fossil oral teeth are known from the Early to Middle Eocene of France, Belgium and North Africa (Hovestadt \& HovestadtEuler 1995; Adnet 2006; Underwood et al. 2011), from the Miocene of Slovakia and Germany (Jaekel 1890; Underwood \& Schlögl 2013), and from the Oligocene of Belgium (Steurbaut \& Herman 1978). Figure 5 shows the modern distribution of the genus Pristiophorus and Pliotrema (Figure 4). This enumeration implies that the genus Pristiophorus also was common in the Atlantic Ocean, unlike to the distribution today.

Pliotrema is scarcely known in the fossil record e.g. Case (1973) figured a rostral spine of Pliotrema sp. from the Miocene Cape Town Formation, Milteron of South Africa and Welton (1974) recovered Pliotrema rostral spines from the Paleocene Lodo Formation of California. The Cenozoic distribution of that species stands in strong contrast to the recent distribution (see Figure 5).

This listing demonstrates that records of sawsharks from the Southern Hemisphere are very scarce. The oldest Southern Hemisphere come from the Early Cretaceous of Australia (Kemp 1991) but should be considered as ambiguous because 

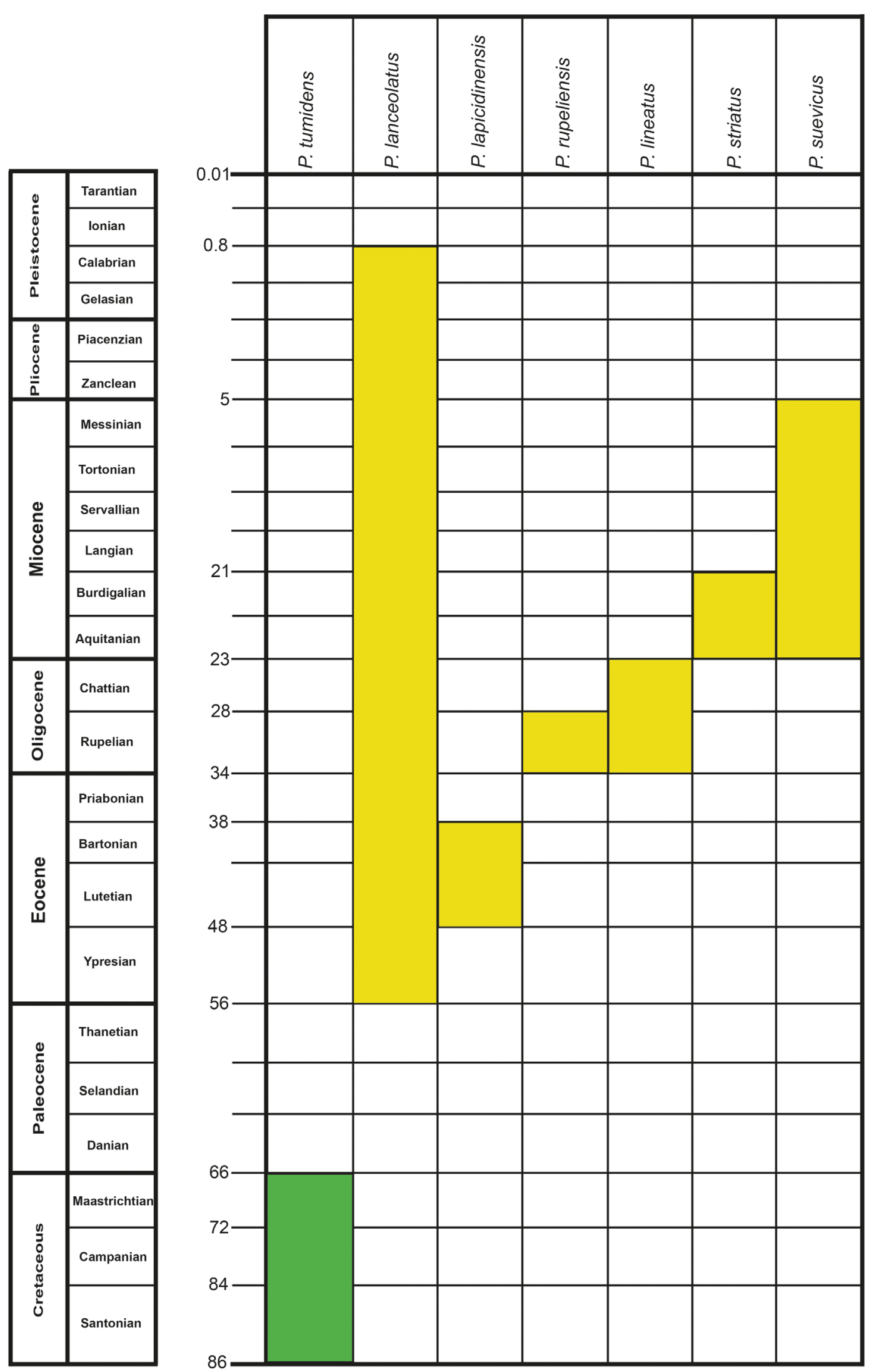

Figure 4. Stratigraphic ranges of all extinct Pristiophorus species known to date. The oldest known representative of sawsharks is Pristiophorus tumidens from the Cretaceous. One species of Pristiophorus, P. lanceolatus has the widest range and is known from the Ypresian until the Pleistocene. From the Oligocene two species, $P$. rupeliensis and $P$. lineatus are known. $P$. striatus is known from the Miocene of the Vienna basin of Slovakia. $P$. suevicus is a Miocene species. $P$. lapicidinensis is known from the Eocene in France. 


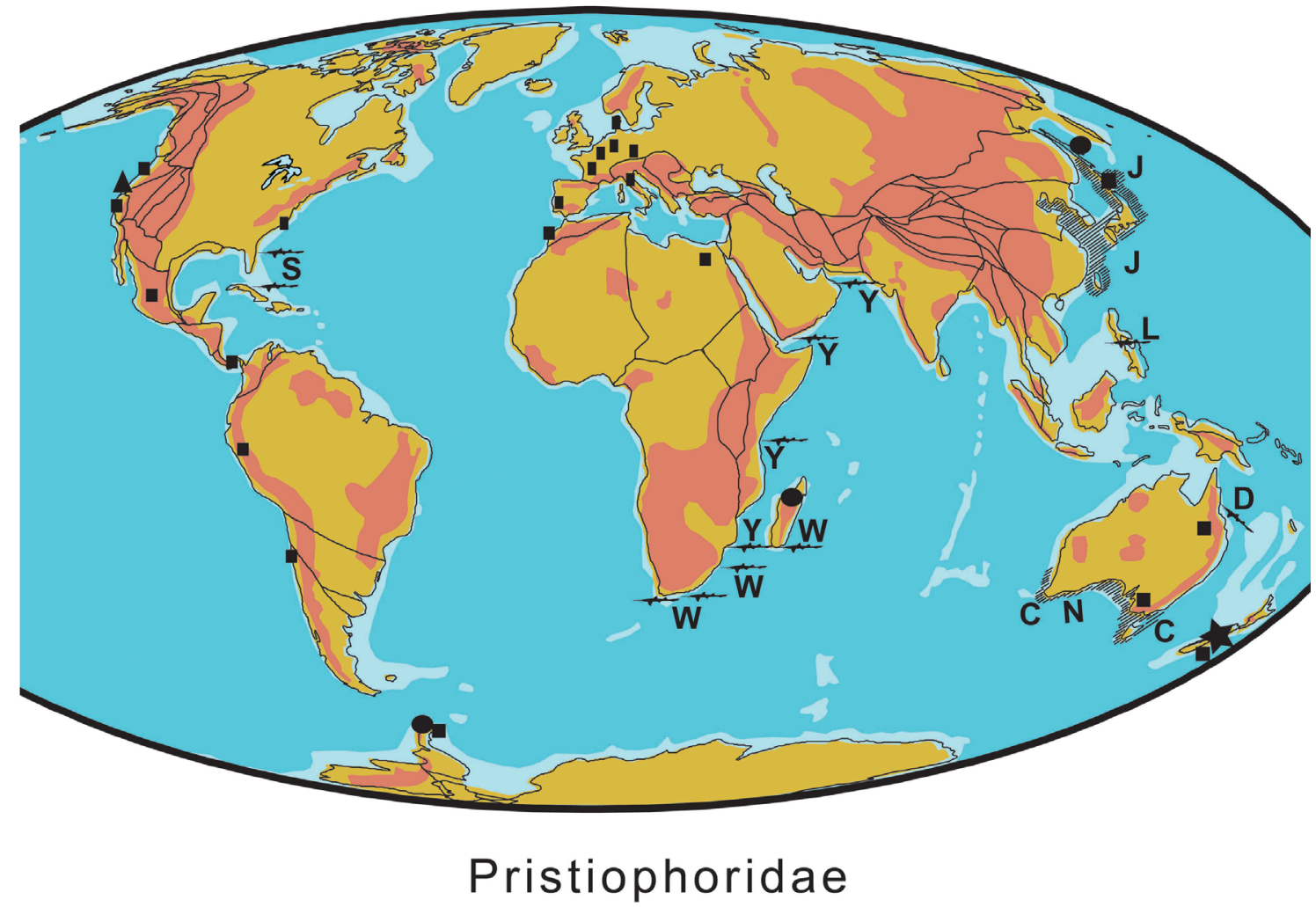

Fossil distribution

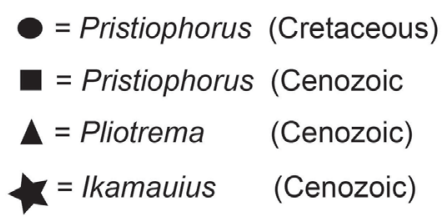

\section{Recent distribution}

$$
\begin{aligned}
\mathbf{W} & =\text { Pliotrema warreni } \\
\mathbf{S} & =\text { Pristiophorus schroederi } \\
\mathbf{C} & =\text { Pristiophorus cirratus } \\
\mathbf{N} & =\text { Pristiophorus nudipinnis } \\
\mathbf{Y} & =\text { Pristiophorus nancyae } \\
\mathbf{L} & =\text { Pristiophorus lanae } \\
\mathbf{J} & =\text { Pristiphorus japonicus } \\
\mathbf{D} & =\text { Pristiophorus delicatus }
\end{aligned}
$$

Figure 5. Distribution of extinct and extant Pristiophoridae. Fossil pristiophorid taxa are marked with symbols, and extant taxa are characterized with capital letters.

no description and figures were provided. Recently Otero et al. (2014) reported the first fossil occurrence of Pristiophorus in the Late Cretaceous (late Maastrichtian) of Seymour Island (Lopez de Bertodano Formation).

In the Eocene La Meseta and Submeseta formations, rostral spines occur in all TELMs but are unequally distributed. The majority of rostral sawshark spines is found in TELMs 4 and 5 (Long 1992a; Kriwet 2005; Reguero et al. 2012; Kriwet et al. 2016), when sea surface temperatures were about $10-11^{\circ} \mathrm{C}$ (e.g. Ivany et al. 2008). Conversely, sawshark remains are more rare in TELMs 6 and 7. The last records come from the uppermost parts of TELM 7, which are Priabonian (Late Eocene) in age (Grande \& Eastman 1986; Tambussi et al. 2006; Kriwet et al. 2016). The decline in abundance from TELMs 4 and 5 to TELM 7 as expressed by raw specimen numbers correlates with a drop in sea surface temperature to about $7-8{ }^{\circ} \mathrm{C}$ shortly before the onset of West Antarctic glaciation and the final disappearance of chondrichthyans from Antarctic waters (Kriwet et al. 2016).

\section{Conclusion}

Pristiophorid sawshark remains from the Eocene of Seymour Island, Antarctica are well known but consisted exclusively of isolated rostral spines. Bulk sampling of shell lenses in the Cucullaea I Allomember of TELM 5, which is late Ypresian in age, at two fossil sites, IAA 1/90 and IAA 2/, yielded four isolated oral and seven rostral spines of a new pristiophorid sawshark. This new material allows a re-evaluation of all previous pristiophorid accounts from Antarctica and from Gondwana in general. The dental material allows establishing a new pristiophorid species, Pristiophorus laevis 
sp. nov. Rostral spines from the Eocene of Seymour Island are assigned to this species, whereas all other Gondwanan records of Pristiophorus lanceolatus are considered to be undiagnostic. The highest abundance of Pristiophorus laevis sp. nov. occurs in TELMs 4 and 5 (Ypresian), when sea surface water temperatures were $10-11^{\circ} \mathrm{C}$. The abundance of sawfish remains decreases from TELM 5 to 7 when the sea surface temperatures dropped to $7-8^{\circ} \mathrm{C}$. Pristophorid sawsharks seemingly vanished from Antarctic waters when extensive Antarctic glaciation started.

\section{Acknowledgement}

The Argentinian Antarctic Institute (IAA-DNA), Argentinian Air Force and Swedish Polar Research Secretariat (SPFS) are acknowledged for logistic support for field-work on Seymour Island. The authors are grateful to Martin de los Reyes, Museo de La Plata, for picking the small fractions in the laboratory.

\section{Disclosure statement}

No potential conflict of interest was reported by the authors.

\section{Funding}

This work was supported by The Austrian Science Fund [FWF grant number P26465-B25] to J.K.; the Swedish Research Council [VR grant number 2009-4447] to T.M.; the Consejo Nacional de Investigaciones Científicas y Técnicas [CONICET grant number PIP 0462] to M.R.; and the Argentinian National Agency for Promotion of Science and Technology [ANPCyT grant number PICTO 0093/2010] to M.R.

\section{References}

Adnet S. 2000. Les élasmobranches fossiles du Paléogène des Landes (SudOuest, France). Implications dans la connaissance des communautés délasmobranches d'eaux profondes. Evolution des Squaliformes et paléoécologie [dissertation]. 211 p., 23 fig., annexes, 40 pl., Montpellier: Université Montpellier II.

Adnet S. 2006. Two new selachian associations (Elasmobranchii, Neoselachii) from the Middle Eocene of Landes (southwest of France). Implication for the knowledge of deep-water selachian communities. Palaeo Ichthyologica. 10:5-128.

Applegate S, Uyeno T. 1968. The first discovery of a fossil tooth belonging to the shark genus Heptranchias, with a new Pristiophorus spine, both from the Oligocene of Japan. Bull Nat Sci Mus, Tokyo. 11:190-200.

Arratia G, Cione AL. 1996. The fish fossil record of southern South America. Münch Geowiss Abh. 30A:9-72.

Berg LS. 1958. System Rezenten und fossilen Fischartigen und Fisch [System of recent and fossil fishy specimens and fishes]. Berlin: Hochschulbücher für Biologie; p. 310.

Bleeker P. 1859. Enumeratio specierum piscium hucusque in Archipelago indico obervatarum [Enumeration of the fish species in the distant Indian Archipelago Indian observatorium]. Acta Soc R Sci IndoNeerlandae. 6:1-276.

Bomfleur B, Mörs T, Ferraguti M, Reguero MA, McLoughlin S. 2015. Fossilized spermatozoa preserved in a 50-Myr-old annelid cocoon from Antarctica. Biol Lett. 11:20150431.

Bonaparte CLJ. 1838. Selachorum tabula analytica [Analytical selachian tables]. Nuovi Ann Sci Nat Bologna. 1:195-214.

Bond M, Pascual R, Reguero MA, Santillan SN, Marenssi SA. 1990. Los primeros "ungulados" extinguidos sudamericanos de la Antártida [The first extinct "Ungulates" from South America in Antarctica]. Ameghiniana. 26:240.

Buono MR, Fernandez MS, Reguero MA, Marenssi SA, Santillana SN, Mörs T. 2016. Eocene basilosaurid whales from the La Meseta Formation, Marambio (Seymour) Island, Antarctica. Ameghiniana. 53:296-315.
Cappetta H. 1980. Les sélaciens du Crétacé supérieur du Liban. I: Requins [Selachians of the Upper Cretaceous of Lebanon. I: Sharks.]. Palaeontographica Abt A. A168:69-148.

Cappetta H.2012. Chondrichthyes: Mesozoic and CenozoicElasmobranchii: Teeth. In: Schultze H-P, editor. Handbook of paleoichthyology. Munich: Verlag Dr. Friedrich Pfeil; Vol. 3E; p. 1-512.

Case GR. 1973. Fossil sharks: a pictorial review. New York (NY): Private Publication, Pioneer Litho Co.; p. 64.

Chapman F. 1918. Description and revisions of the Cretaceous and Tertiary fish-remains of New Zealand. N Z Geol Surv Pal Bull. 7:1-45.

Cione AL. 1988. Los peces de las formaciones marinas terciarias del Cenozoico de Patagonia [The fishes of the Tertiary and Cenozoic marine formations of Patagonia]. [Doctoral Thesis (unpublished)]. Facultad de Ciencias Naturales y Museo, Universidad Nacional de La Plata; p. 536.

Cione AL, Expósito E. 1980. Chondrichtyes (Pisces) del "Patagoniano", s.l. de Astra, Golfo de San Jorge, Prov. De Chubut, Argentina. Su significación paleoclimática y paleobiogeográfica [Chondrichthyes (Pices) of "Patagonia", s.l. of Astra, San Jorge Gulf, Province of Chubut, Argentina. Its paleoclimatic and paleobiografic significance]. Actas del II Congreso Argentino de Paleontología y Bioestratigrafía y del I Congreso Latinoamericano de Paleontología. Buenos Aires. 2:275-290.

Cione AL, Reguero MA. 1998. A middle Eocene basking shark (Lamniformes, Cetorhinidae) from Antarctica. AntarctSci. 10:83-88. doi: 10.1017/S095410209800011X.

Compagno LJV. 1973. Interrelationship of the living elasmobranchs. Zool J Linn Soc. 53:15-61.

Compagno LJV. 1977. Phyletic relationships of living sharks and rays. Am Zool. 17:303-322.

Compagno LJV, Dando M, Fowler S. 2005. A field guide to the sharks of the world. London: Harper Collins; p. 1-368.

Davies JW. 1888. On fossil-fish remains from the Tertiary and CretaceoTertiary formations of New Zealand. Sci Trans Roy Dublin Soc. 4:1-63.

De Muizon C, De Vries TJ. 1985. Geology and paleontology of late Cenozoic marine deposits in the Sacaco area (Peru). Geol Rundsch. 74:547-563.

Doktor M, Gazdzicki A, Jerzmanska A, Porebski SJ, Zastawniak E. 1996. A plant and fish assemblage from the Eocene La Meseta Formation of Seymour Island (Antarctic Peninsula) and its environmental implications. Palaeontol Pol. 55:127-146.

Ebert DA, Cailliet GM. 2011. Pristiophorus nancyae, a new species of Sawshark (Chondrichthyes: Pristiophoridae) from Southern Africa. Bull Mar Sci. 87:501-512.

Ebert DA, Winton MV. 2010. Chondrichthyans of High Latitude Seas. In: Carrier JC, Musick JA, Heithaus MJ, editors. Sharks and their relatives II-biodiversity, adaptive physiology and consevation. Boca Raton (FL): CRC Press; p. 116-158.

Elliot DH, Trautman TA. 1982. Lower Tertiary strata on Seymour Island, Antarctic Peninsula. In: Craddock C, editor. Antarctic geoscience. Madison (WI): University of Wisconsin Press; p. 287-297.

Frazzetta T. 1994. Feeding mechanisms in sharks and other elasmobranchs. In: Bels VL, Chardon M, Vandewalle P, Aerts P, editors. Biomechanics of feeding in vertebrates. Berlin: Springer-Verlag; p. 31-57.

Gazdzicki A, Gruszczynski M, Hoffman A, Malkowski K, Marenssi SA, Halas S, Tatur A. 1992. Stable carbon and oxygen isotope record in the Paleogene La Meseta formation, Seymour Island, Antarctica. Antarct Sci. 4:461-468.

Gelfo JN, Mörs T, Lorente M, López GM, Reguero M. 2015. The oldest mammals from Antarctica, early Eocene of La Meseta Formation, Seymour Island. Palaeontology. 58:101-110.

Grande L, Chatterjee S. 1987. New cretaceous fish fossils from Seymour island, Antarctic Peninsula. Palaeontology. 30:829-837.

Grande L, Eastman JT. 1986. A review of Antarctic ichthyofaunas in the light of new fossil discoveries. Palaeontology. 29:113-137.

Hay OP. 1902. Bibliography and catalogue of the fossil vertebrata of North America. US Geol Survey Bull. 179:1-868.

Herman J. 1973. Contribution à la connaissance de la faune ichthyologique des phosphates du Maroc [Contribution to the knowledge of the fish fauna of the Morocco phosphates]. Ann Soc Géol Belg. 95:271-284.

Hovestadt DC, Hovestadt-Euler M. 1995. Additions to the fauna of the Boom Clay Formation of Belgium (Rupelian, Oligocene). Taxonomic adjustments on the Scyliorhinidae and Rajoidei, discovery of a dasyatid 
species (Pisces, Chondrichthyes) and of a curculionid species (Insecta, Coleoptera). Belg Geol Surv Prof Pap. 278:261-282.

Huxley TH. 1880. On the application of the laws of evolution to the arrangement of the Vertebrata, and more particularly of the Mammalia. Proc Zool Soc Lond. 43:649-662.

Ivany LC, Lohmann KC, Hasiuk F, Blake DB, Glass A, Aronson RB, Moody RM. 2008. Eocene climate record of a high southern latitude continental shelf: Seymour Island, Antarctica. Geol Soc Am Bull. 120:659-678. doi: 10.1130/B26269.1.

Jadwiszczak P, Mörs T. 2011. Aspects of diversity in early Antarctic penguins. Acta Palaeontol Pol. 56:269-277.

Jadwiszczak P, Mörs T. 2016. First report on quill pits in early penguins. Antarct Sci. 28:217-218.

Jaekel O. 1890. Ueber die systematische Stellung und über fossile reste der gattung Pristiophorus [On the systematic position and on fossil remains of the genus Pristiophorus]. Z Dtsch Geol Ges. 42:86-120.

Kemp NR. 1991. Chondrichthyans in the Cretaceous and Tertiary of Australasia. In: Vickers-Rich P, Monaghan JM, Baird RF, Rich TH, editors. Vertebrate palaeontology of Australasia. Melbourne: Monash University; Lilydale: Pioneer Design Studio Pty Ltd; p. 497-568.

Keyes IW. 1979. Ikamauius, a new genus of fossil sawshark (Order Selachii: Family Pristiophoridae) from the Cenozoic of New Zealand. New Zeal J Geol Geop. 22:125-129.

Keyes IW. 1982. The Cenozoic sawshark Pristiophorus lanceolatus (Davies) (Order Selachii) of New Zealand and Australia, with a review of the phylogeny and distribution of world fossil and extant Pristiophoridae. New Zeal J Geol Geop. 25:459-474.

Kriwet J. 2003. First record of Early Cretaceous shark (Chondrichthyes, Neoselachii) from Antarctica. Antarct Sci. 15:519-523.

Kriwet J. 2004. The systematic position of the Cretaceous sclerorhynchid sawfishes (Elasmobranchii, Pristiorajea). In: Arratia G, Tintori A, editors. Mesozoic Fishes 3: Systematics, Paleoenvironments and Biodiversity. München: Verlag Friedrich Pfeil; p. 57-73.

Kriwet J. 2005. Additions to the Eocene selachian fauna of Antarctica with comments on Antarctic selachian diversity. J Vert Paleontol. 25:1-7.

Kriwet J, Benton MJ. 2004. Neoselachian (Chondrichthyes, Elasmobranchii) diversity across the Cretaceous-Tertiary boundary. Palaeogeogr Palaeoclimatol Palaeoecol. 214:181-194.

Kriwet J, Engelbrecht A, Mörs T, Reguero MA, Pfaff C. 2016. Ultimate Eocene (Priabonian) chondrichthyans (Holocephali, Elasmobranchii) of Antarctica. J Vert Paleontol. 36:e1160911.

Latham J. 1794. An essay on the various species of Sawfish. Trans Linn Soc Lond. 2:273-282.

Lawley R. 1876. Nuovi studi sopra ai pesci i altri vertebrati fossili delle Colline Toscane [New studies about fishes and other fossil vertebrates from the Tuskany hills]. Florence: Tipografia dell Arte della Stampa; p. 122.

Long DJ. 1992a. Sharks from the La Meseta Formation (Eocene), Seymour Island, Antarctic Peninsula. J Vert Paleontol. 12:11-32. doi: 10.1080/02724634.1992.10011428.

Long DJ. 1992b. Paleoecology of Eocene Antarctic sharks. Antarct Res Ser. 56:131-139.

Marenssi SA. 2006. Eustatically controlled sedimentation recorded by Eocene strata of the James Ross Basin, Antarctica. In: Francis J, Crame JA, editors. Cretaceous-Tertiary High-Latitude Palaeoenvironments, James Ross Basin, Antarctica. London: Geological Society, Special Publications; , Vol. 258; p. 125-133.

MarenssiSA, Reguero MA, Santillana SN, Vizcaino SF. 1994. Review: Eocene land mammals from Seymour Island, Antarctica: paleobiogeographical implications. Antarct Sci. 6:3-15.

Marenssi SA, Santillana SN, Rinaldi CA. 1998a. Paleoambientes sedimentarios de la Aloformacio'n La Meseta (Eoceno), Isla Marambio (Seymour), Antártida [Sedimentary paleoenvironments of the La Meseta Aloformation (Eocene), Island Marambio (Seymour), Antarctica]. Contrib cien Inst Ant Argentino. 464:1-51.

Marenssi SA, Santillana SN, Rinaldi CA. 1998b. Stratigraphy of the La Meseta Formation (Eocene), Marambio (Seymour) Island, Antarctica. In: Casadio S, editor. Paleógeno de América del Sur y de la Península Antártica: Asociación Paleontológica Argentina. Publicación Especial. Buenos Aires: Asociación Paleontológica Argentina; Vol. 5; p. 137-146.
McLoughlin S, Bomfleur B, Mörs T, Reguero M. 2016. Fossil clitellate annelid cocoons and their microbiological inclusions from the Eocene of Seymour Island, Antarctica. Palaeontol Electron. 19.1.11A:1-27.

Michaux B. 2009. Reciprocality between biology and geology: reconstructing polar Gondwana. Gondwana Res. 16:655-668.

Montes M, Nozal F, Santillana S, Marenssi S, Olivero E. 2013. Mapa Geológico de Isla Marambio (Seymour), Antártida, escala 1: 20.000 [Geological Map of the Marambio Island (Seymour), Antarctica, scale 1: 20,000]. $1^{a}$ ediciòn, Serie Cartográfica. Buenos Aires: IGME.

Müller J, Henle J. 1837. Gattungen der Haifische und Rochen nach einer von ihm mit Hrn. Henle unternommenen gemeinschaftlichen Arbeit über die Naturgeschichte der Knorpelfische [Genera of sharks and rays, after a communal work after a communal work with Henle about the natural History of cartilaginous fishes]. BerKgl Preuss Akad Wiss Berlin. 1837:111-118.

Musick JA, Harbin MM, Compagno LJV. 2004. Historical zoogeography of the selachii. In: Carrier JC, Musick JA, Heithaus MR, editors. The biology of sharks and their relatives. Boca Raton (FL): CRC Press; p. 33-78.

Nishimoto H, Morozumi Y. 1979. Late Cretaceous elasmobranchs from the Izumi Mountain Range. Bull Mizunami Fossil Mus. 6:133-140.

Noubhani A, Cappetta H. 1997. Les Orectolobiformes, Carcharhiniformes et Myliobatiformes (Elasmobranchii, Neoselachii) des Bassins à phosphate du Maroc (Maastrichtien-Lutétien basal). Systématique, biostratigraphie, évolution et dynamique des faunes. Palaeo Ichthyologica. 8:1-327.

Otero RA, Gutstein CS, Vargas A, Rubilar-Rogers D, Yury-Yañez R, Bastías J, Ramírez C. 2014. New chondrichthyans from the Upper Cretaceous (Campanian-Maastrichtian) of Seymour and James Ross islands, Antarctica. J Paleontol. 88:411-420.

Pollerspöck J, Straube N. 2016. World Wide Web electronic publication, Version 2016. [cited 2016 Jul 28]. Available from: www.shark-references. com/post/639

Regan CT. 1906. Descriptions of new or little-known fishes from the coast of Natal. Ann Natal Mus. 1:1-6.

Reguero M, Goin F, Acosta Hospitaleche C, Dutra T, Marenssi S. 2013. The terrestrial biotic dimension of West Antarctica (WANT). In: Reguero M, Goin F, Acosta Hospitaleche C, Dutra T, Marenssi S, editors. Late Cretaceous/Paleogene West Antarctica Terrestrial Biota and its Intercontinental Affinities. Dordrecht: Springer Netherlands; p. 55-110.

Reguero MA, Marenssi SA, Santillana SN. 2012. Weddellian marine/coastal vertebrate diversity from a basal horizon (Ypresian, Eocene) of the Cucullaea I Allomember, La Meseta formation, Seymour (Marambio) Island, Antarctica. Rev Peru Biol. 19:275-284.

Sadler PM. 1988. Geometry and stratification of uppermost Cretaceous and Paleogene units on Seymour Island, northern Antarctic Peninsula. In: Feldmann RM, Woodburne MO, editors. Geology and Paleontology of Seymour Island, Antarctic Peninsula. Geol Soc Am Mem. 169;303320.

Schwarzhans W, Mörs T, Engelbrecht A, Reguero M, Kriwet J. 2016. Before the freeze: otoliths from the Eocene of Seymour Island, Antarctica, reveal dominance of gadiform fishes (Teleostei). J Syst Palaeontol. 1-24.

Schweitzer C, Feldmann R, Marenssi S, Waugh DA. 2005. Remarkably preserved annelid worms from the La Meseta Formation (Eocene), Seymour Island, Antarctica. Palaeontology. 48:1-13.

Smith MM, Riley A, Fraser GJ, Underwood C, Welten M, Kriwet J, Pfaff C, Johanson Z. 2015. Early development of rostrum saw-teeth in a fossil ray tests classical theories of the evolution of vertebrate dentitions. Proc R Soc Lond B Biol Sci. 282:20151628.

Springer S, Bullis HR Jr. 1960. A new species of sawshark, Pristiophorus schroederi, from the Bahamas. Bull Mar Sci. 10:241-254.

Steurbaut E, Herman J. 1978. Biostratigraphie et Poissons fossilesde la formation de l'Argile de Boom (Oligocène moyen du Bassin Belge) [Biostratigraphy and fossil fishes of the Boom clay formation (Middle Oligocene of the Belgian basin]. Geobios. 11:297-325.

Stilwell JD, Zinsmeister WJ. 1992. Molluscan systematics and biostratigraphy: lower Tertiary La Meseta Formation, Seymour Island, Antarctic Peninsula. Antarct Res Ser. 55:1-192.

Suárez ME, Encinas A, Ward DJ. 2006. An Early Miocene elasmobranch fauna from the Navidad Formation, Central Chile, South America. Cainozoic Res. 4:3-18. 
Suárez ME, Marquardt C. 2001. Neogene selachians from the Bahía Inglesa Formation, North of Chile. Actas de XVII Jornadas Argentinas de Paleontología Vertebrados. Esquel, Chubut; p. 37.

Tambussi CP, Acosta Hospitaleche CI, Reguero MA, Marenssi SA. 2006. Late Eocene penguins from West Antarctica: systematics and biostratigraphy. In: Francis JE, Pirrie D, Crame JA, editors. CretaceousTertiary High-Latitude Paleoenvironments, James Ross Basin, Antarctica. London: Geological Society London; p. 145-161.

Underwood CJ, Schlögl J. 2013. Deep-water chondrichthyans from the early Miocene of the Vienna Basin (Central Paratethys, Slovakia). Acta Palaeontol Pol. 58:487-509.

Underwood CJ, Ward DJ, King C, Antar SM, Zalmout IS, Gingerich PD. 2011. Shark and ray faunas in the Middle and Late Eocene of the Fayum Area, Egypt. Proc Geol Assoc. 122:47-66.
Vaughan APM, Pankhurst RJ. 2008. Tectonic overview of the West Gondwana margin. Gondwana Res. 13:150-162.

Welton BJ. 1972. Fossil sharks in Oregon. ORE BIN. 34:161-172.

Welton BJ. 1974. Preliminary note on the Paleocene elasmobranchs of the Lodo Formation, Fresno County, California. In: Pacific Section, S. E. P. M., Fall Guidebook for the Paleogene of the Panoche Creek-Cantua Creek area, Central California; p. 91-97.

Wueringer BE, Squire L, Kajiura SM, Hart NS, Collin SP. 2012. The function of the sawfish's saw. Curr Biol. 22:R150-R151.

Woodward AS. 1932. A Cretaceous pristiophorid shark. J Nat Hist. 10: 476-478.

Zinsmeister WJ. 1982. Late Cretaceous-early Tertiary molluscan biogeography of the southern circum-Pacific. J Paleontol. 84-102. 